\title{
Correction to: Health-related quality of life in breast cancer patients: review of reviews from 2008 to 2018
}

Parisa Mokhtari-Hessari ${ }^{1,2}$ and Ali Montazeri ${ }^{2,3^{*}}$ (1)

\section{Correction to: Health Qual Life Outcomes (2020) 18:338} https://doi.org/10.1186/s12955-020-01591-x

The original article contained an error in co-author, Parisa Mokhtari-Hessari's name which has since been corrected.

\section{Author details}

'Integrative Oncology Research Group, Breast Cancer Research Center, Motamed Cancer Institute, ACECR, Tehran, Iran. ${ }^{2}$ Population Health Research Group, Health Metrics Research Center, Iranian Institute for Health Sciences Research, ACECR, Tehran, Iran. ${ }^{3}$ Faculty of Humanity Sciences, University of Science and Culture, ACECR, Tehran, Iran.

Published online: 25 February 2022

\section{Publisher's Note}

Springer Nature remains neutral with regard to jurisdictional claims in published maps and institutional affiliations. original author(s) and the source, provide a link to the Creative Commons licence, and indicate if changes were made. The images or other third party material in this article are included in the article's Creative Commons licence, unless indicated otherwise in a credit line to the material. If material is not included in the article's Creative Commons licence and your intended use is not permitted by statutory regulation or exceeds the permitted use, you will need to obtain permission directly from the copyright holder. To view a copy of this licence, visit http://creativecommons.org/licenses/by/4.0/. The Creative Commons Public Domain Dedication waiver (http://creativeco mmons.org/publicdomain/zero/1.0/) applies to the data made available in this article, unless otherwise stated in a credit line to the data. 